\section{PLEASE NOTE:}

This publication was produced in 2006 and some information is out of date. Please see UC ANR's Asian Citrus Psyllid website https:// ucanr.edu/sites/ACP/) for current information.

\title{
Asian Citrus Psyllid
}

ELIZABETH E. GRAFTON-CARDWELL, University of California, Riverside, and UC Kearney Agricultural Center, Parlier; KRIS E. GODFREY, California Department of Food and Agriculture, Sacramento; MICHAEL E. ROGERS, University of Florida Citrus Research and Education Center, Lake Alfred; CARL C. CHILDERS, University of Florida Citrus Research and Education Center, Lake Alfred; and PHILIP A. STANSLY, University of Florida Southwest Florida Research and Education Center, Immokalee

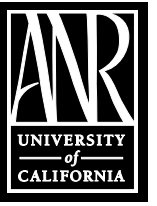

The Asian citrus psyllid, Diaphorina citri Kuwayama (Homoptera: Psyllidae) (fig. 1) is a pest of citrus and close relatives of citrus. Asian citrus psyllid damages plants directly through its feeding activities. New shoot growth that is heavily infested by psyllids does not expand and develop normally and is more susceptible to breaking off. While direct damage is serious, there is even greater concern that the psyllid is an efficient vector of the bacterium that causes the economically devastating disease cit-

UNIVERSITY OF CALIFORNIA

Division of Agriculture and Natural Resources http://anrcatalog.ucdavis.edu

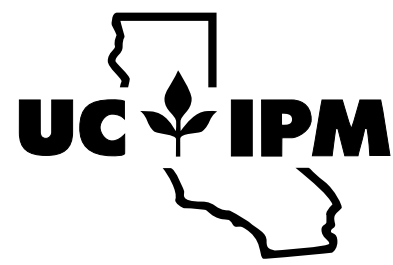

\section{UC Exotic/Invasive Pest and Disease Program}

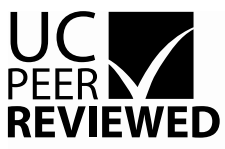
rus greening, or Huanglongbing.

Asian citrus psyllid is found in tropical and subtropical Asia, Afghanistan, Saudi Arabia, Reunion, Mauritius, parts of South and Central America, Mexico, and the Caribbean (fig. 2). In the United States, Asian citrus psyllid was first found in Palm Beach County, Florida, in June 1998 in backyard plantings of Murraya paniculata (orange jasmine) (fig. 3). By 2001, it had spread to 31 counties in Florida, with much of the spread due to movement of infested nursery plants (Halbert et al. 2002). In the spring of 2001, Asian citrus psyllid was accidentally introduced into the Rio Grande

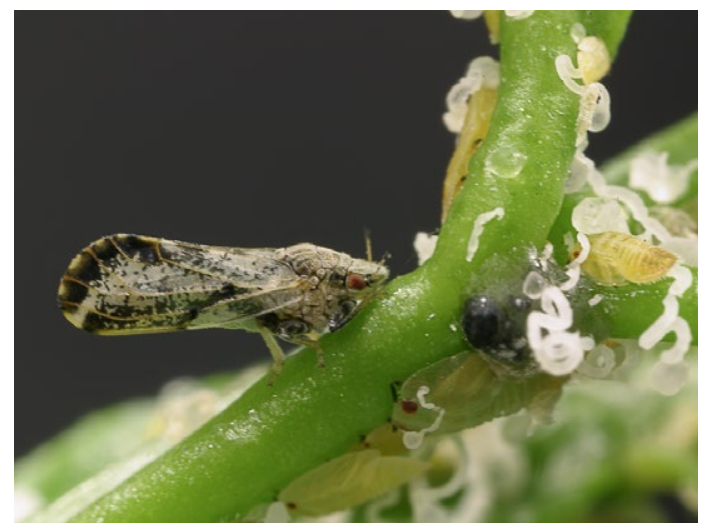

Figure 1. Asian citrus psyllid adult and nymphs. Photo by M. E. Rogers.

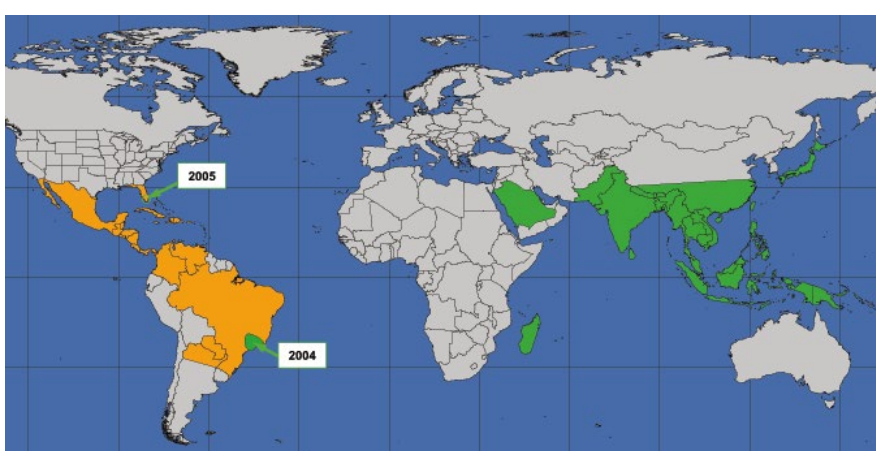

Figure 2. Worldwide distribution of Asian citrus psyllid alone (orange) and the psyllid in combination with the Asian form of greening disease (green). Illustration by G. H. Montez.
Valley of Texas on potted nursery stock (orange jasmine) from Florida (French et al. 2001). The Asian citrus psyllid could invade California at any time, with most likely sources of infestation being Florida, Mexico, or Asia. There were 170 interceptions of Asian citrus psyllid at U.S. ports on plant material (primarily Murraya and citrus) from Asia from 1985 to 2003.

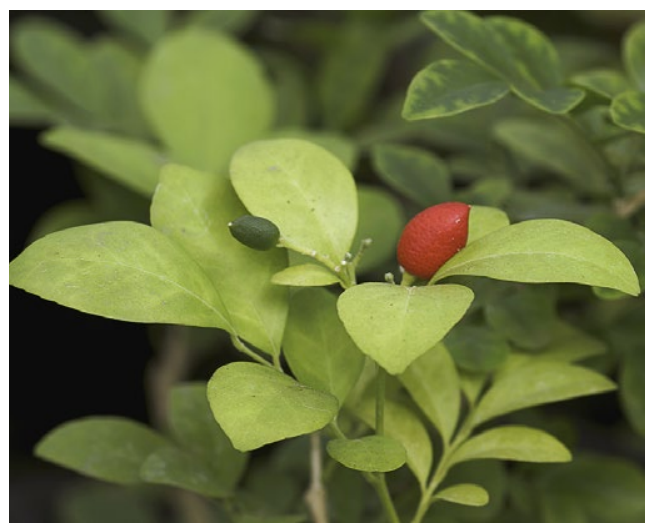

Figure 3. Murraya paniculata, orange jasmine. Photo by E. E. Grafton-Cardwell. 


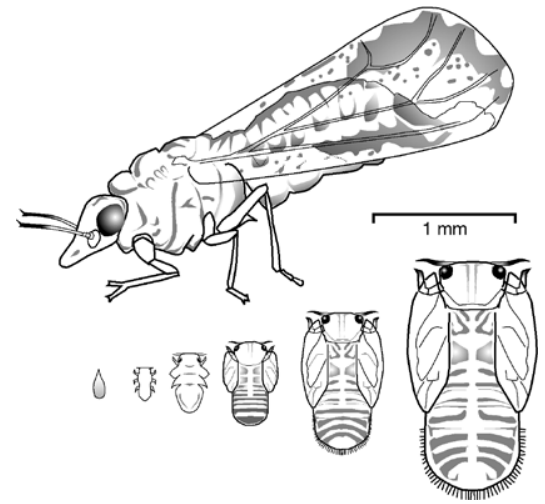

Figure 4. Life cycle of Asian citrus psyllid. Illustration by G. O. Conville after Catling 1970.

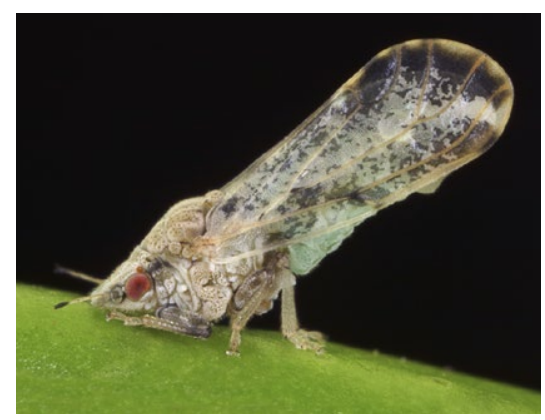

Figure 5. Psyllid adult feeding.

Photo by M. E. Rogers.

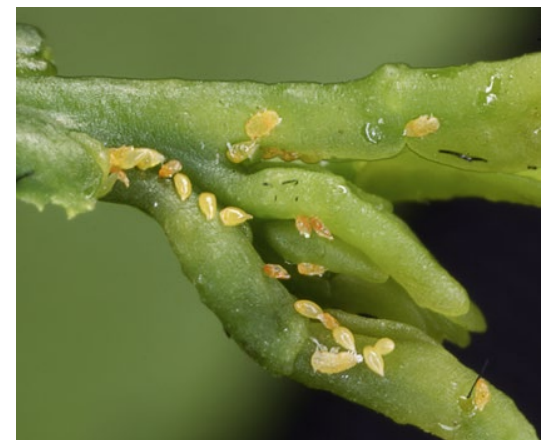

Figure 6. Psyllid eggs and hatching nymphs. Photo by M. E. Rogers.

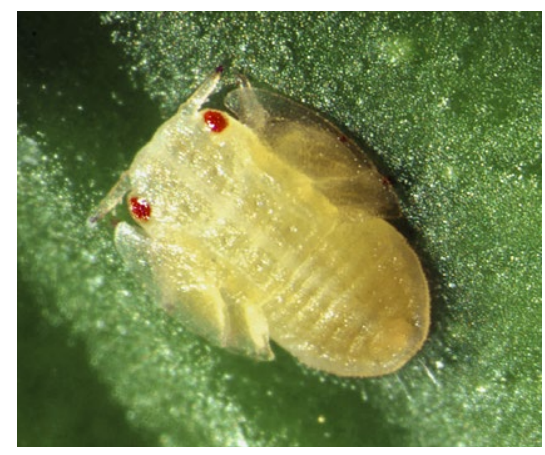

Figure 7. 5th instar psyllid nymph. Photo by M. E. Rogers.

Citrus greening disease was first detected in the United States in Florida in 2005. It is found throughout Asia, the Indian subcontinent and neighboring islands, the Saudi Arabian peninsula, and since 2004 in the São Paulo state of Brazil. The citrus greening pathogen is transmitted by psyllid vectors, grafting, and possibly by citrus seed. A disease-free citrus budwood program combined with detection and eradication of Asian citrus psyllid are essential components of the program that protects the California citrus industry from citrus greening disease.

\section{HOST PLANTS}

The host range of Asian citrus psyllid includes 25 genera in the family Rutaceae, although not all of these are good hosts (Halbert and Manjunath 2004). The most common or preferred hosts are in the genera Citropsis, Citrus, and Murraya (see fig. 3). Because of its restricted host range, monitoring efforts for this pest should be focused on all varieties of citrus and closely related plants.

\section{PSYLLID LIFE CYCLE}

Psyllids are small insects, 3 to $4 \mathrm{~mm}$ (1/8 to 1/6 inch) in length with a simple life cycle that progresses from egg through 5 nymphal instars to the adult stage (fig. 4).

\section{ADULTS}

Adult Asian citrus psyllids are brownish and usually feed on the underside of leaves. They feed with their heads down, almost touching the surface of the leaf. Because of the shape of their head, their bodies are lifted off the leaf at about a $45^{\circ}$ angle (fig. 5). The adults will jump or fly a short distance when disturbed (Mead 1977). Adults live for 1 to 2 months, and their life span is influenced by temperature and host plant (Liu and Tsai 2000). The abdomen of an adult female turns bright yellow-orange after she becomes gravid.

\section{E G GS}

Asian citrus psyllid females lay their bright yellow-orange, almond-shaped eggs on the tips of growing shoots or in the crevices of unfolded "feather flush" leaves (fig. 6). The number of eggs laid is dependent upon host plant. For example, a mean of 857 eggs per female was deposited on grapefruit, whereas a mean of 572 eggs per female was deposited on rough lemon. At $77^{\circ} \mathrm{F}\left(25^{\circ} \mathrm{C}\right)$, the eggs hatch in about 4 days (Tsai and Liu 2000).

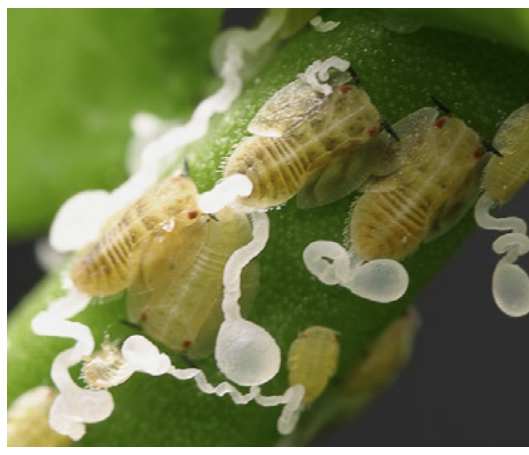

Figure 8. Waxy tubules produced by nymphs. Photo by M. E. Rogers.

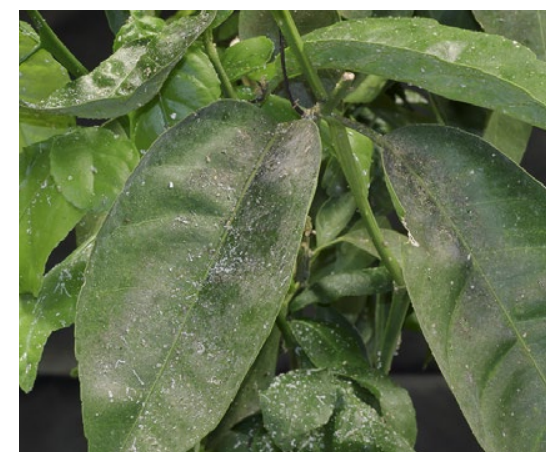

Figure 9. Sooty mold growing on the honeydew excreted by the nymphs. Photo by M. E. Rogers. 


\section{NYMPHS}

Asian citrus psyllid nymphs ( 0.25 to $1.7 \mathrm{~mm}$ [0.01 to 0.07 inch] in length) are generally yellowish-orange in color (fig. 7) and feed exclusively on new growth. The nymphs move in a slow, steady manner and flick their abdomens upward when disturbed. There are five nymphal stages (5 instars) that look similar, but increase in size after each molt (see fig. 4). The later instars have large wing pads. The feeding nymphs produce waxy tubules that direct the honeydew away from their bodies (fig. 8). Nymphal survival rates vary with citrus variety. Nymphs must have young tender flush to survive, and this portion of the population declines when leaves harden off.

\section{MATURITY}

Development from egg to adult requires 16 to 17 days at $77^{\circ} \mathrm{F}\left(25^{\circ} \mathrm{C}\right)$. If it were to experience uniformly warm conditions with suitable flush continuously present, the Asian citrus psyllid could complete up to 30 generations per year. However, humidity, temperature, and host plant effects play a role in the survival and developmental rate of this psyllid. Survivorship of adult Asian citrus psyllid is best at humidities above 53 percent, but there is significant survival at humidities as low as 7 percent (McFarland and Hoy 2001). Asian citrus psyllid does not diapause, but it does decrease in density when citrus is not flushing because the immature stages require flushing plant material. Asian citrus psyllid adults are present year-round in southern Florida on orange jasmine, a common ornamental shrub. Densities of the psyllid peak in May, August, and October through December in southern Florida (Tsai et al. 2002). This coincides with new flush growth in the orange jasmine. This plant is thought to serve as an alternate host for Asian citrus psyllid when citrus is not in flush because of its more continuous flushing pattern.

\section{DAMAGE CAUSED TO CITRUS BY ASIAN CITRUS PSYLLID FEEDING}

Asian citrus psyllid directly damages citrus and closely related ornamentals (Halbert and Manjunath 2004). Psyllids extract large quantities of sap from the plant as they feed and produce copious amounts of honeydew. The honeydew coats the leaves of the tree, encouraging sooty mold to grow (fig. 9).

In addition, as Asian citrus psyllid feeds, it injects a salivary toxin that stops terminal elongation and causes malformation of leaves and shoots (fig. 10) (Michaud 2004). A single psyllid nymph feeding for less than 24 hours on a citrus leaf causes permanent malformation of that leaf. Overwintering adults aggregate on newly forming citrus leaf buds where they feed and mate. Often, initial infestations of Asian citrus psyllids are highly aggregated on individual trees within citrus orchards. This aggregation and feeding causes distortion of the leaf buds that provides improved oviposition sites. Citrus flush is often severely damaged (figs. 11 and 12), resulting in the abscission of the leaves and shoots (Halbert and Manjunath 2004) or malformed mature leaves (fig. 13). Mature trees can tolerate this damage since the loss of leaves or shoots is only a small portion of the total tree canopy. Nursery trees and new plantings may require chemical protection.

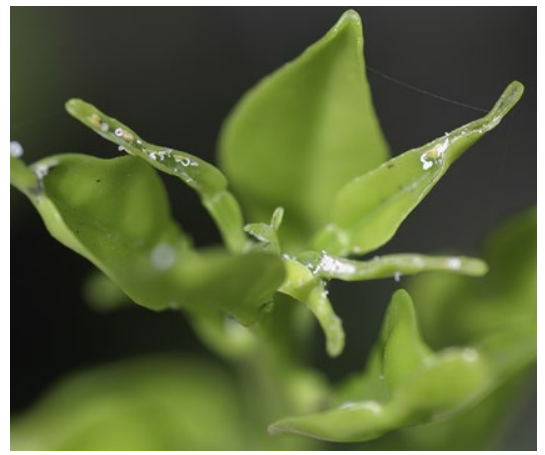

Figure 10. Twisted tips of new citrus flush due to psyllid feeding. Photo by E. E. Grafton-Cardwell.

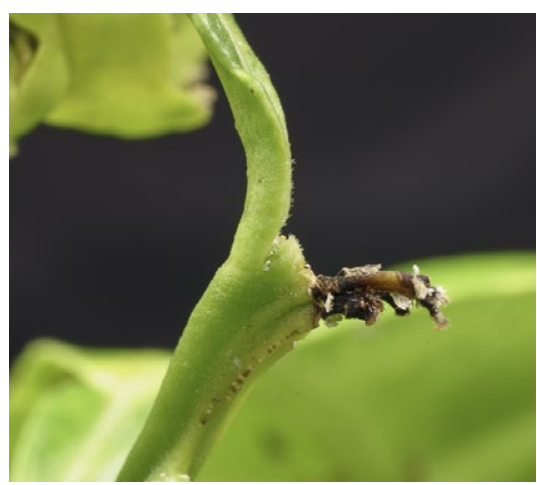

Figure 11. Burnt tip of citrus foliage due to psyllid feeding. Photo by M. E. Rogers.

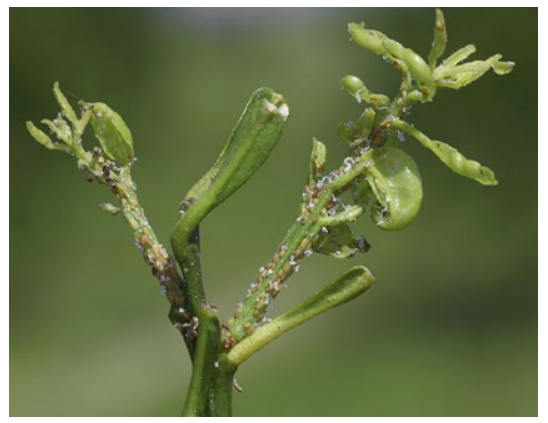

Figure 12. Malformed citrus leaves due to psyllid feeding. Photo by M. E. Rogers.

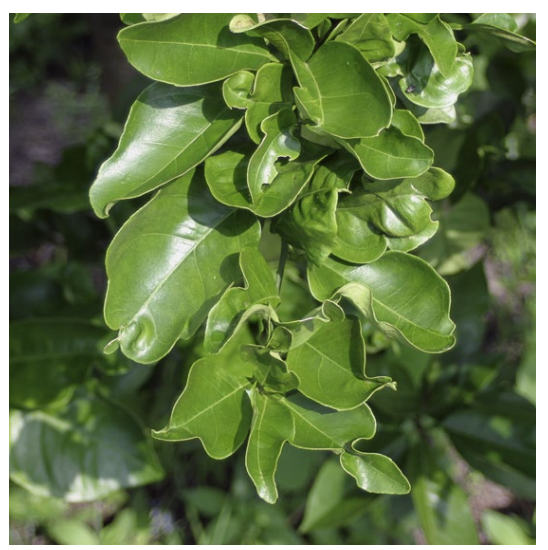

Figure 13. Distorted citrus leaves due to previous psyllid feeding. Photo by M. E. Rogers. 


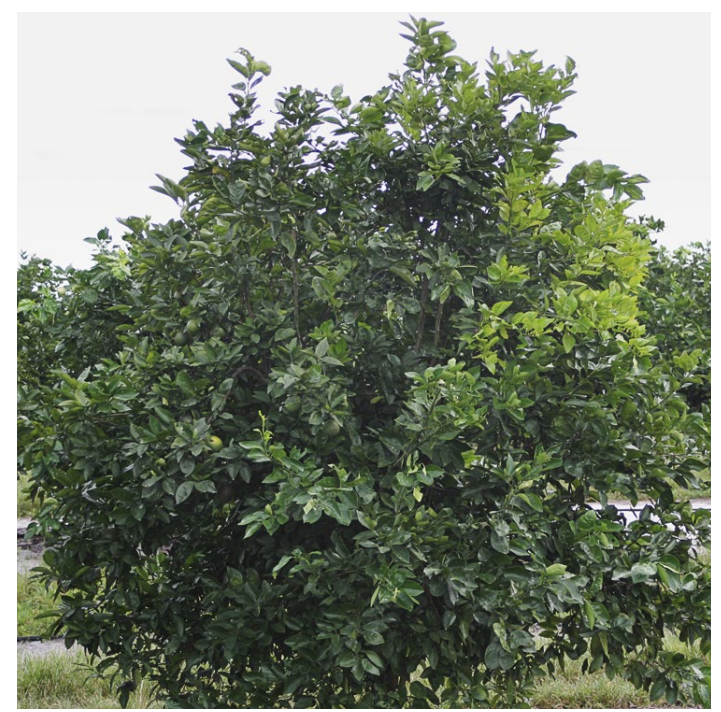

Figure 14. Yellowing of a quadrant of a citrus tree due to greening. Photo by M. E. Rogers.

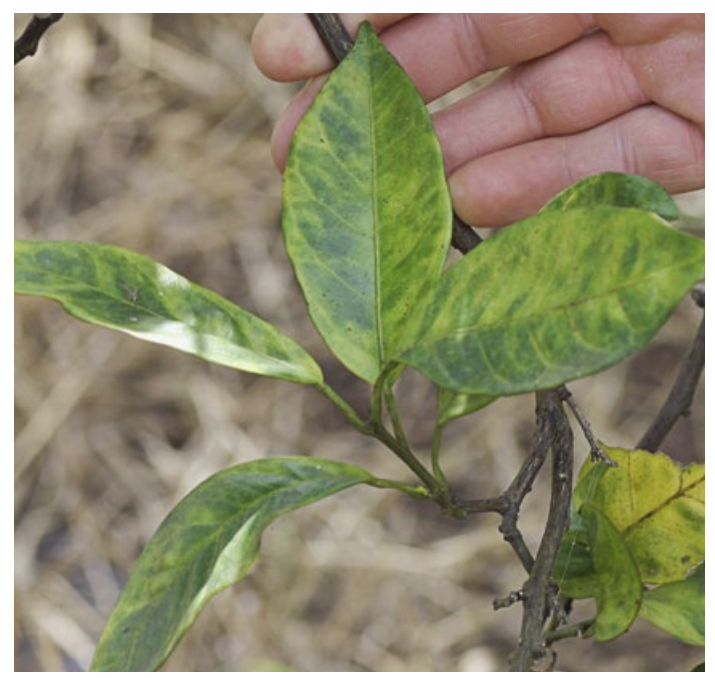

Figure 15. Chlorosis of citrus leaves due to greening caused by L. asiaticus. Photo by M. E. Rogers.

\section{ASIAN CITRUS PSYLLID AND CITRUS GREENING DISEASE}

The most serious damage caused by Asian citrus psyllid is due to its ability to efficiently vector the phloem-inhabiting bacterium Candidatus Liberibacter asiaticus that causes citrus greening disease (Huanglongbing). In the past, this bacterium has been extremely hard to detect and characterize. In recent years, however, DNA probes, electron microscopy, and ELISA tests have been developed that have improved detection (Roistacher 1991, Garnier and Bové 1993, Bové et al. 1996).

Symptoms of citrus greening include yellow shoots (fig. 14) and mottling and chlorosis of the leaves (Capoor et al. 1974). The mottling superficially resembles zinc deficiency. However, the mottling associated with citrus greening disease does not run only along the veins as in zinc deficiency, but will cross leaf veins (fig. 15). Infected trees are stunted, sparsely foliated, and may bloom off-season. In addition, there is twig dieback, leaf and fruit drop, and production of small, lopsided, hard fruit with small, dark, aborted seeds (fig. 16). The juice of the infected fruit has a bitter taste. Fruit do not color properly, leading to the name "greening". Citrus greening is one of the most devastating diseases of citrus in the world. Antibiotics injected into infected citrus trees provide only temporary remission of symptoms. In parts of Asia, citrus greening has substantially reduced the amount of citrus that can be grown (Salibe and Cortez 1966, Catling 1970).

The Asiatic form of citrus greening disease is found throughout the warmer areas of Asia, India, and the Saudi Arabian peninsula (see fig. 2). In July 2004, both L. asiaticus and L. americanus isolates of citrus greening disease were detected in Brazil, where they were found to be affecting orchards in São Paulo state (Texeira et al. 2005). In 2005, L. asiaticus was detected in Florida. Citrus greening has not been found in California. The host range of L. asiaticus and L. americanus is limited to citrus and closely related relatives of citrus. Thus, disease monitoring efforts should be directed towards these plant species. If you suspect that you have trees infected with citrus greening, contact your local county agricultural commissioner's office.

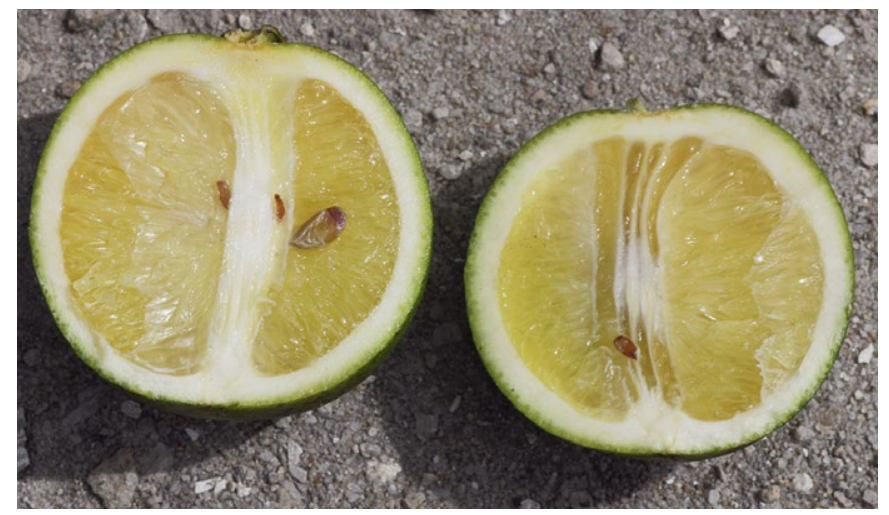

Figure 16. Small, lopsided fruit, dark seeds, and rind that does not color properly due to greening. Photo by M. E. Rogers. 


\section{MONITORING FOR ASIAN CITRUS PSYLLID IN CALIFORNIA}

Monitoring should be conducted by visually inspecting the new flush of citrus (fig. 17) and ornamental nursery plants such as orange jasmine (M. paniculata) that potentially act as hosts of Asian citrus psyllid. Monitoring should include a search for all insect stages, including the gray to brownish adults (fig. 18) and the brightly colored yellow-orange eggs and nymphs (fig. 19). Adults jump easily and should be collected with an aspirator. Eggs and small nymphs are difficult to see without a hand lens. Nymphs flatten themselves around the shoot, and eggs are tucked inside crevices and leaf folds. Special attention should be given to damage caused by Asian citrus psyllid, including twisted and curling shoot tips, sooty mold, and white waxy deposits on the leaves (figs. 20 and 21). Yellow or green sticky cards can be used as an additional method for detecting adult psyllids (fig. 22).

If you suspect that you have found this psyllid, place the infested plant in a container or place adults and nymphs in alcohol and contact your local county agricultural commissioner's office for identification. If the find is determined to be Asian citrus psyllid, the extent of the infestation will be delineated using visual surveys, and the appropriate regulatory actions will be taken to minimize the spread of Asian citrus psyllid from the site. Regulatory steps may include infested plant destruction, insecticidal treatment of plants around the infestation, quarantine of the area, and additional surveys and treatments of the area during periods of new flush.

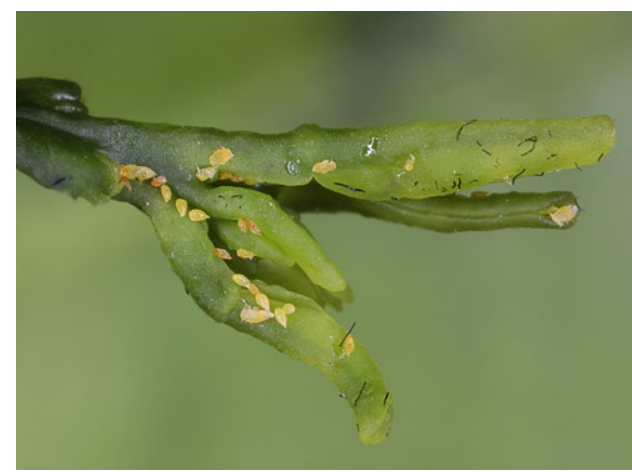

Figure 19. Psyllid eggs and nymphs tucked into crevices and folds. Photo by M. E. Rogers.

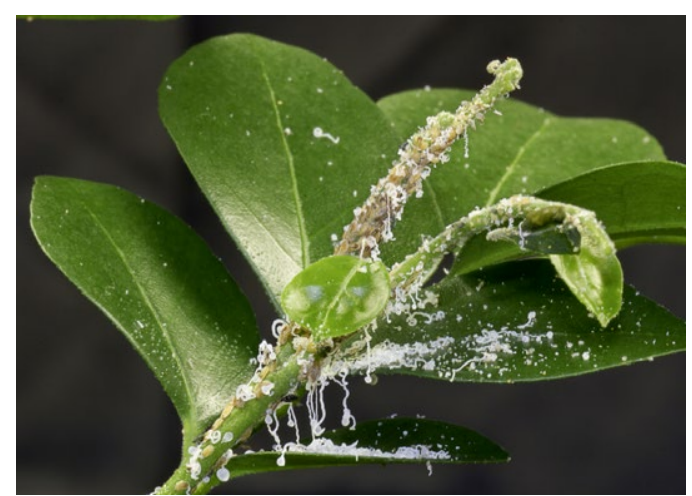

Figure 21. Heavy infestation of psyllids on Murraya. Photo by M. E. Rogers.
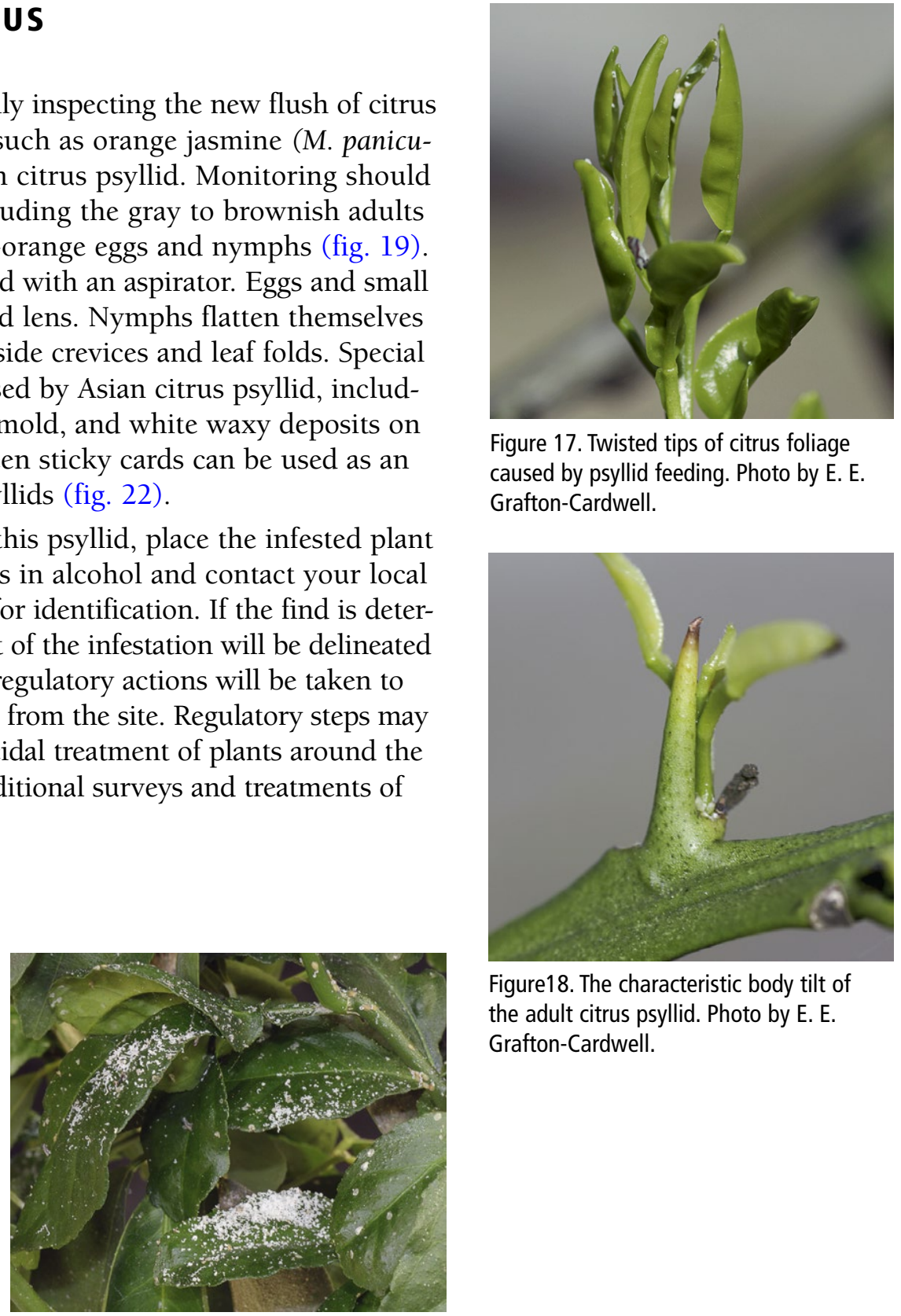

Figure 17. Twisted tips of citrus foliage caused by psyllid feeding. Photo by E. E. Grafton-Cardwell.

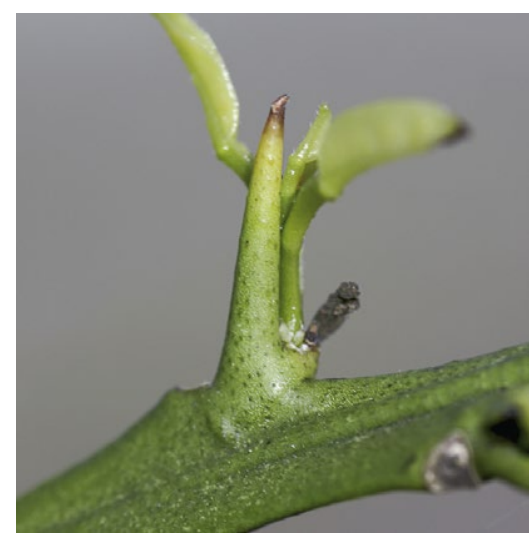

Figure18. The characteristic body tilt of the adult citrus psyllid. Photo by E. E. Grafton-Cardwell.
Figure 20. Honeydew, sooty mold, and waxy tubules produced by psyllids. Photo by M. E. Rogers.

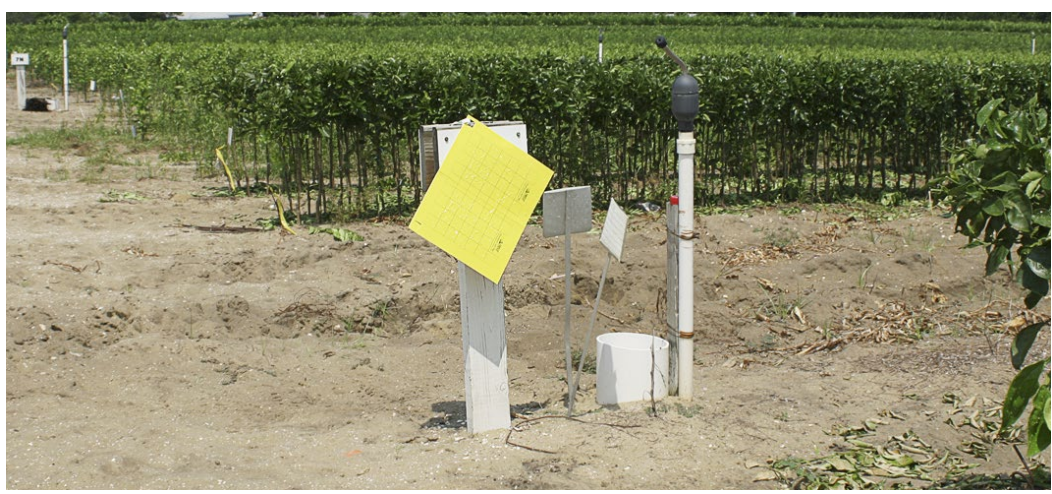

Figure 22. Yellow sticky card for adult psyllid detection. Photo by M. E. Rogers. 


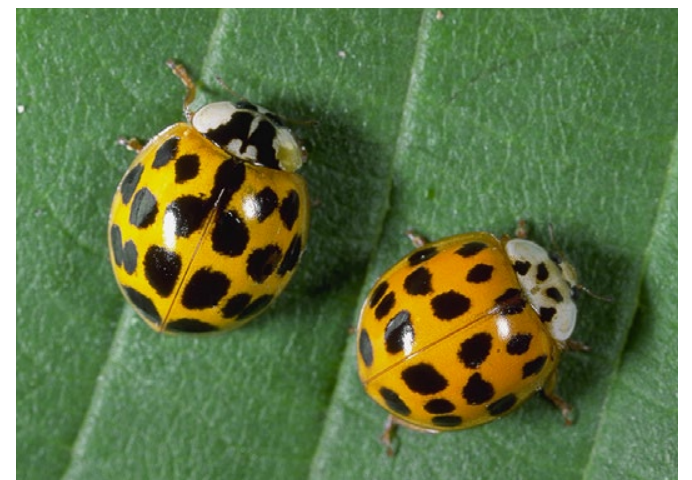

Figure 23. Harmonia axyridis coccinellid predatory beetles. J. K. Clark

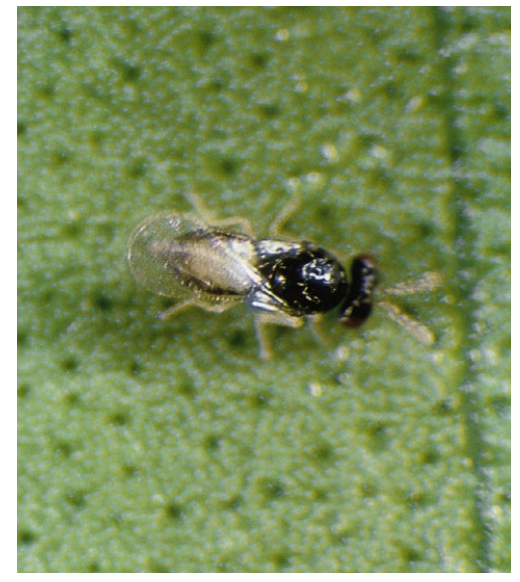

Figure 24. Tamarixia radiata parasitic wasp. Photo by M. A. Hoy.

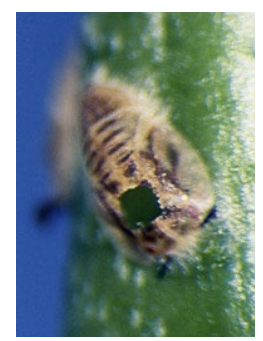

Figure 25 Exit hole in a dead psyllid, indicating previous parasitism. Photo by M. A. Hoy.

\section{LONG-TERM MANAGEMENT OF ASIAN CITRUS PSYLLID IN FLORIDA}

Asian citrus psyllid is now established throughout Florida, and integrated pest management (IPM) practices have been developed to help reduce the direct damage it causes to citrus. If this pest were detected in California, host plant destruction and chemical control would be used to eradicate it. If the pest were to become established in California and citrus greening were not present, biological control tactics would be implemented similar to those used in Florida.

\section{CHEMICAL CONTROL}

In Florida, where eradication of the psyllid is not possible, chemical control is used to reduce the direct damage that psyllids cause to the flush tissue of young trees. Generally, only nurseries and new plantings are treated because mature citrus trees can withstand the physical injury caused by the psyllid. Young trees are protected from psyllids by applying Admire (imidacloprid) as a systemic insecticide. Uptake of Admire is a function of tree size and soil type, since smaller trees or seedlings take up Admire more rapidly than larger trees. Because the action of Admire is fairly slow, this treatment is often combined with a broad-spectrum foliar application of a neonicotinoid or a pyrethroid for more immediate control.

\section{BIOLOGICAL CONTROL}

Populations of Asian citrus psyllid in Florida are fed upon by many generalist arthropod predators such as spiders, lacewings, hover flies or syrphids, and minute pirate bugs, and are attacked by a number of parasites (Michaud 2004). The Coccinellid predatory beetles exert the greatest amount of control of psyllid populations.

\section{COCCINELLID PREDATORY BEETLES}

Two lady beetles, Olla v-nigrum (Mulsant) and Harmonia axyridis Pallas (fig. 23), are the most important predators of Asian citrus psyllid nymphal populations in Florida. On some terminals, all Asian citrus psyllid nymphs are eaten by immature and adult stages of these lady beetles.

\section{HYMENOPTEROUS PARASITES}

Two tiny wasp parasites of Asian citrus psyllid nymphs have been imported, investigated for safety to the environment, and released in Florida. The parasite Tamarixia radiata (Waterston) (fig. 24) was imported from Taiwan and Vietnam, and the parasite Diaphorencyrtus aligarhensis (Shaffee, Alam and Agarwal) was imported from Taiwan. Both parasites were released in Florida with apparently only T. radiata establishing (McFarland and Hoy 2001). The wasp lays its eggs underneath the psyllid nymph, and the wasp larva feeds on and kills the psyllid. The parasite emerges as an adult from underneath the dead psyllid or through a hole that it chews in the body of the psyllid (fig. 25). 


\section{LITERATURE CITED}

Bové, J. M., N. M. Chau, H. M. Trung, J. Bourdeaut, and M. Garnier. 1996. Huanglongbing (greening) in Viet Nam: Detection of Liberobacter asiaticum by DNA-hybridization with probe In2.6 and PCR-amplification of 16S ribosomal DNA. Proceedings of the 13th Conference, International Organization of Citrus Virologists. 258-266.

Capoor, S. P., D. G. Rao, and S. M. Viswanath. 1974. Greening disease of citrus in the Deccan Trap Country and its relationship with the vector, Diaphornia citri, Kuwayama. Proceedings of the 6th Conference, International Organization of Citrus Virologists. 43-49.

Catling, H. D. 1970. Distribution of the psyllid vectors of citrus greening disease with notes on the biology and bionomics of Diaphorina citri. FAO Plant Protection Bulletin 18:8-15.

French, J. V., C. J. Kahlke, and J. V. da Graca. 2001. First record of the Asian citrus psylla, Diaphorina citri Kuwayama (Homoptera: Psyllidae) in Texas. Subtropical Plant Science 53:14-15.

Garnier, M., and J. M. Bové. 1993. Citrus greening disease. Proceedings of the 12th Conference, International Organization of Citrus Virologists. 212-219.

Halbert, S. E., and K. L. Manjunath. 2004. Asian citrus psyllids (Sternorrhyncha: Psyllidae) and greening disease of citrus: A literature review and assessment of risk in Florida. Florida Entomologist 87:330-353.

Halbert, S. E., C. L. Niblett, K. L. Manjunath, R. F. Lee, and L. G. Brown. 2002. Establishment of two new vectors of citrus pathogens in Florida. Proceedings of the International Society of Citriculture 9th Congress. Alexandria, VA: ASHS Press. 1016-1017.

Liu, Y. H., and J. H. Tsai. 2000. Effects of temperature on biology and life table parameters of the Asian citrus psyllid, Diaphorina citri Kuwayama (Homoptera: Psyllidae). Annals of Applied Biology 137:201-216.

McFarland, C. D., and M. A. Hoy. 2001. Survival of Diaphorina citri (Homoptera: Psyllidae), and its two parasitoids, Tamarixia radiata (Hymenoptera: Eulophidae) and Diaphorencyrtus aligarhensis (Hymenoptera: Encyrtidae) under different relative humidities and temperature regimes. Florida Entomologist 84:227-233.

Mead, F. W. 1977. The Asiatic citrus psyllid, Diaphorina citri Kuwayama (Homoptera: Psyllidae). Florida Department of Agriculture Conservation Service, Division of Plant Industry Entomology Circular No. 180. Florida DPI Web site, http://www.doacs.state.fl.us/ pi/enpp/ento/entcirc/Entcirc180.pdf.

Michaud, J. P. 2004. Natural mortality of Asian citrus psyllid (Homoptera: Psyllidae) in Central Florida. Biological Control 29:260-269.

Roistacher, C. N. 1991. Techniques for biological detection of specific citrus graft transmissible diseases. In C. N. Roistacher, Graft-transmissable diseases of citrus. Rome: FAO, 1991. 35-45.

Salibe, A. A., and R. E. Cortez. 1966. Studies on the leaf mottling disease of citrus in the Philippines. FAO Plant Protection Bulletin 14:141-144.

Texeira, D. C., J. Ayres, E. W. Kitajima, L. Danet, S. Jagoueix-Eveillard, C. Saillard, and J. M. Bové. 2005. First report of a huanglongbing-like disease of citrus in São Paulo State, Brazil and association of a new Liberibacter species, "Candidatus Liberibacter americanus," with the disease. Plant Disease 89:107.

Tsai, J. H., and Y. H. Liu. 2000. Biology of Diaphorina citri (Homoptera: Psyllidae) on four host plants. Journal of Economic Entomology 93: 1721-1725.

Tsai, J. H., J. J. Wang, and Y. H. Liu. 2002. Seasonal abundance of the Asian citrus psyllid, Diaphorina citri (Homoptera: Psyllidae), in southern Florida. Florida Entomologist 85:446-451. 
To order or obtain printed ANR publications and other products, visit the ANR Communication Services online catalog at http://anrcatalog.ucdavis.edu. You can also place orders by mail, phone, or FAX, or request a printed catalog of our products from:

University of California

Agriculture and Natural Resources

Communication Services

6701 San Pablo Avenue, 2nd Floor

Oakland, California 94608-1239

Telephone: (800) 994-8849 or (510) 642-2431

FAX: (510) 643-5470

E-mail inquiries: danrcs@ucdavis.edu

An electronic version of this publication is available on the ANR Communication Services Web site at http://anrcatalog.ucdavis.edu.

Publication 8205

ISBN-13: 978-1-60107-396-9

ISBN-10: 1-60107-396-8

(C) 2006 by the Regents of the University of California, Division of Agriculture and Natural Resources. All rights reserved.

The University of California prohibits discrimination or harassment of any person on the basis of race, color, national origin, religion, sex, gender identity, pregnancy (including childbirth, and medical conditions related to pregnancy or childbirth), physical or mental disability, medical condition (cancer-related or genetic characteristics), ancestry, marital status, age, sexual orientation, citizenship, or status as a covered veteran (covered veterans are special disabled veterans, recently separated veterans, Vietnam era veterans, or any other veterans who served on active duty during a war or in a campaign or expedition for which a campaign badge has been authorized) in any of its programs or activities. University policy is intended to be consistent with the provisions of applicable State and Federal laws.

Inquiries regarding the University's nondiscrimination policies may be directed to the Affirmative Action/Staff Personnel Services Director, University of California, Agriculture and Natural Resources, 1111 Franklin Street, 6th Floor, Oakland, CA 94607-5201 (510) 987-0096. For a free catalog of other publications, call (800) 994-8849. For help downloading this publication, call (530) 297-4445.

To simplify information, trade names of products have been used. No endorsement of named or illustrated products is intended, nor is criticism implied of similar products that are not mentioned or illustrated.

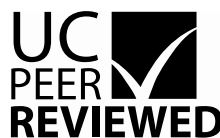

This publication has been anonymously peer reviewed for technical accuracy by University of California scientists and other qualified professionals. This review process was managed by the ANR Associate Editor for Pest Management.

This publication was produced with funding from the University of California Exotic and Invasive Pests and Diseases Research Program and the California Citrus Research Board.

12m-pr-6/06-SB/RW 